\title{
Study on the Environmental Materials with the Disposal Measures of the
}

\section{Benzene Leakage Accidents}

\author{
Yuanyuan Wang, Bingqiang Wang
}

Kunming fire-fighting command school of public security fire forces, Kunming, Yunnan Province, China

1009541492@qq.com

Keywords: Benzene leakage accident harm environmental materials disposal measures Abstract. In recent years, the higher frequency occurrence of benzene leakage accident brings great harm to the country and people's life and property. This paper analyses the types, hazards and accidents measures to dispose of dangerous chemical accident.

\section{Introduction}

Benzene is important petrochemical materials, which is mainly used in the industry of pesticides production, dyes and explosives manufacturing. In recent years, benzene is widely used in industrial production, as a result, in the process of production, storage, transportation and use of benzene, the benzene leakage accident happen from time to time. Benzene has flammable and toxic properties, once the container and pipeline are broken because of an explosion and fire, benzene will leak out. the leaked benzene also can burn and explode. The continuous benzene leakage accident resulting in a large number of casualties and severe economic losses to the people's life, economic construction and influence in politics. For example, on November 13, 2005, there was an benzene leakage and explosion accident in the double benzene plant of Jilin Petrochemical Company. In the process of accident, 5000 tons of water and 28 tons of foam were consumed, the leaked benzene and the fire water are discharged into the Songhua River. Consequently, it caused serious water pollution and brings about significant environmental pollution accident.

\section{Benzene accident type}

Fire accident. Benzene is a flammable and explosive substances, it immediately burn or explode after it occurs leakage if it meets the fire source.

Poisoning and pollution accident. Benzene is toxic, people breathe or skin of the body contact will appear headache, nausea, vomiting and other symptoms of poisoning, and it has the carcinogenic risk. If benzene flow into the water and permeate the soil, it will cause the serious ecological environment pollution.

\section{Benzene leakage accident harm}

In the past few years, the use of benzene increases considerably, so the frequency of leakage and explosion accident increases, which has brought human numerous casualties and huge economic losses. At the same time, the accident can cause serious environmental pollution, posing a great threat to the sustainable development of human society. The frequency of benzene leakage and explosion accident increase because of its wide variety, its extensive range of usage and 
circulation; Benzene leakage accident has the characteristics of fast spreading speed, wide impact scope, high toxicity and it is difficult to cope with and decontaminate.

\section{The environmental materials}

The elimination of harm caused by dangerous chemicals accident is an important link in disposal of chemical accidents, and decontamination is elimination of toxic hazards and pollution area. The dangerous chemicals accident can be achieved to reduce the harm according to physical decontamination method handled by activated carbon absorption .

Activated carbon is a carbon material (coal, shells, wood shavings, etc.) made of hydrophobic adsorbent, including granular activated carbon and pulverous activated carbon。It is a kind of environmental material. It can absorb: pesticides, aromatic hydrocarbon organic matter and color material ,etc. Particle size of granular activated carbon is $1.5 \sim 3 \mathrm{~mm}$, which is used to advanced treatment after conventional treatment in water works and pollution accident disposal (granular activated carbon filter dam, etc.).Pulverous activated carbon of 200 mesh or 325 mesh (coal char)and 100 mesh (wood charcoal) is used for water intensive preprocessing (before coagulation dosing) and short-term water quality deterioration in water works.

In the urban water supply emergency treatment of the Songhua River water pollution accident, multiple security barriers of the emergency response process are formed by the pulverous activated carbon and granular activated carbon, namely pulverous activated carbon is thrown in the intake. Activated carbon for the dangerous chemicals accident is able to regenerate. Activated carbon regeneration is to use physical or chemical method without destroying its original structure to get rid of the adsorbate in activated carbon microvoid and restore its adsorption performance. Regenerative activated carbon can be reused.

\section{The characteristics of benzene leakage accident}

Benzene is vulnerable to occur fire and explosion accident.Benzene immediately burn or explode after it occurs leakage if it meets the fire source.

Benzene has the danger of poisoning. Benzene is toxic, if people breathe or the skin of the body contact ,people will appear headache, nausea, vomiting and other symptoms of poisoning, and it has the carcinogenic risk. Health hazards of different concentrations of benzene vapor on the body.(See table 1).

Table 1 The hazards of benzene vapor on the body

\begin{tabular}{|c|c|c|c|}
\hline \multicolumn{2}{|c|}{$\begin{array}{l}\text { Health hazards of different concentrations of benzene vapor } \\
/ \mathrm{ppm} \\
/\left(\mathrm{mg} / \mathrm{m}^{3}\right)\end{array}$} & The contact time & The reaction \\
\hline $19000 \sim 20000$ & $61000 \sim 64000$ & $5 \sim 10$ & Death \\
\hline 75000 & 24000 & 30 & Life risk \\
\hline 1500 & 4800 & 60 & Severe symptoms of poisoning \\
\hline 500 & 1600 & 60 & General poisoning symptom \\
\hline $50 \sim 150$ & $160 \sim 480$ & 300 & Headache and fatigue \\
\hline
\end{tabular}

Benzene is easy to cause environmental secondary disasters. When benzene occurs leakage or explosion, the leaked benzene or the mixed material or after the explosion can pollute the atmosphere, water and soil. If benzene flow into the water and permeate the soil, it will the cause serious ecological environment pollution. 


\section{The disposal measures of benzene leakage accident}

Because benzene is flammable and toxic, the accident central area should forbid fire and cut off power supply. The firemen should use special protective clothing and isolated air mask. They should train strictly to properly use and adapt, and the firemen should be covered with the water gun and water cannon.

Table 2 Personal protection grade

\begin{tabular}{|c|c|c|c|c|}
\hline Level & Form & Chemical protective clothing & Protectiveclothing & Protective mask \\
\hline One level & Whole body & $\begin{array}{l}\text { The built-in heavy anti } \\
\text { chemical clothes }\end{array}$ & $\begin{array}{l}\text { Cotton anti-static inner, } \\
\text { coat, gloves, socks }\end{array}$ & $\begin{array}{l}\text { Positive pressure air } \\
\text { breathing apparatus }\end{array}$ \\
\hline Two level & Whole body & $\begin{array}{l}\text { Closed chemical } \\
\text { protective clothing }\end{array}$ & $\begin{array}{c}\text { Cotton anti-static inner, } \\
\text { coat, gloves, socks }\end{array}$ & $\begin{array}{l}\text { Positive pressure air } \\
\text { breathing apparatus }\end{array}$ \\
\hline Three level & Breathing & $\begin{array}{c}\text { Simple chemical } \\
\text { protective clothing }\end{array}$ & Battle suit & Simple canister and mask \\
\hline
\end{tabular}

The control measures of benzene leakage. The firemen should close the valve and stop the operation process to reduce load operation. When the benzene leakage occur in the tank area, The firemen should close the valve to prevent the material outflow along the ditch. The spray water flow to the poisonous and harmful gases leakage can accelerate the air diffusion. The environmental materials can be falled into the pits to absorb benzene. The operation can change benzene to low toxic or non-toxic substances.

The explosion disposal measures after benzene occurs leakage. When benzene occur leak, benzene can occur explode. The firemen should actively take the command to quickly cut off the leakage. At the same time, the firemen should take self-protection measures. They should wear protective masks and special protective and so on. The commander should control fire range when the fire breaks out. The fire force should use the cooling and dilution protection measures to prevent the benzene spread after the fire and the explosion. To prevent fire, endangering the adjacent facilities, The fire force shall take measures to cool the surrounding facilities and set water curtain or steam to reduce the concentration of benzene.

\section{Conclusion}

With the social and economic progress, the environmental materials based on the benzene leakage accident disposal will be more and more advanced. When the environmental materials are more advanced, they will play more and more important role. The country should actively promote the relevant knowledge of benzene safety and environmental protection in the whole society to enhance the understanding of the public on the benzene hazards and safety protection measures.

\section{Reference}

[1] Guanghua Zhang. Production safety technology and management of dangerous chemicals [M].Beijing: China petrochemical press, 2004.

[2] Dongxi Xu.The preliminary exploration of collection and treatment of fire wastewater in petrochemical enterprises.Industrial water and wastewater [J].2000, 31 (3) : 51 -52

[3] Min Wang, Zhongping Chen.The emergency disposal for accidental environmental pollution events [J]. City and disaster mitigation, 2006 (6): 19 -21 
[4] Guiguo Bian, Yiyun Zhan, Shande Ying,etc. The emergency monitoring and handling of phenol leakage pollution events, environment and sustainable development [J], 2007 (4): $43-44$

[5] Minyan Liu, Li Qingxiang. Main safety problems and countermeasures in the design of large crude oil storage tank. [ J] . Chinese journal of safety science, 1999, 9 ( 5) : 96- 99.

[6]Fire-fighting and rescue expert group of the Ministry of Public Security. the investigation report about the situation of prevention and reduction of water pollution in accident conditions of dangerous chemical enterprise that can easily cause water pollution in Jilin, Sichuan and Jiangsu provinces [R]. 2007

[7] Tao Cai. Fire, fire control, environmental protection [J]. Journal of science and technology information of China, 2005 (16) : 69

[8]Bureau of safety production and supervision in Liaoning province. Safety management teaching materials of hazardous chemical materials[M]. Shengyang: Northeastern university press, 2003: 39-46.

[10] Jianchi Song, Fan Xiushan. Safety system engineering of chemical plant[M]. Beijing: Chemical industry press, 2004. 